\title{
Domestic R\&D Spillovers and Absorptive Capacity: Some Evidence for US, Europe and Japan
}

\section{(3)}

(1)

(1)

Absorptive capacity is one of the most influential concepts in the management and innovation literature. First introduced by Cohen and Levinthal (1989), it is typically defined as a set of organisational routines and processes that allow firms to assimilate, transform and exploit external knowledge. An aspect that has been ignored by the literature on absorptive capacity is the nature of the knowledge being absorbed. This paper suggests that the learning strategies underpinning absorptive capacity adapt to the type of external knowledge they are more likely to get exposure to and as a result, not all the firms appear to benefit from the same type of external knowledge for the same level of absorptive capacity. To this purpose, we explore how firm-level absorptive capacity mediates the relationship between rent and pure R\&D spillovers on the one hand and firm-level turnover on the other in three economic areas (Europe, Japan and US). The empirical analysis uses a dataset (sourced from the EU R\&D investment scoreboards) made of 879 worldwide R\&D-intensive manufacturing firms. Given the panel data structure of the sample, econometric techniques that deal with unobserved heterogeneity as well as weak exogeneity are employed. The empirical results suggest for the same level of absorptive capacity, firms in economic areas that are closer to the world technology frontier tend to benefit more from pure (knowledge) spillovers than from rent spillovers. Vice versa, firms located in areas that are not on the technology frontier appear to benefit mostly from rent spillovers that travel along the supply chain. These results suggest that absorptive capacity changes with the type of knowledge they may get exposed to.

Keywords: Panel Data Models, R\&D Spillovers, Productivity growth.

JEL codes: $\mathrm{C} 23, \mathrm{O} 33, \mathrm{O} 47$ 


\section{Introduction}

Absorptive capacity is one of the most influential concepts in the management literature. First introduced by Cohen and Levinthal (1989) and then developed by Zahra and George (2002) in the context of a firm's learning and innovation, it is now a by-word for a variety of learning strategies, routines and processes that influence the firm's ability to exploit the external knowledge necessary to build other organizational capabilities (Todorova and Durison, 2007; Zahra and George, 2002). Over the last thirty years, substantial research effort has been devoted to the analysis of the absorptive capacity and its drivers (D'Souza and Kulkarni, 2015). Research on absorptive capacity has mostly focused on two main areas: a) the impact of absorptive capacity on firm-level performance and its ability to sustain competitive advantage (Kanks and Silverstovs, 2016) and b) the internal factors that influence the development of the absorptive capacity itself (see Jansen et al., 2005).

Still much remains to be explored. For instance the literature has largely ignored the role that knowledge attributes play in conditioning the firm's absorptive capacity even if their importance has been highlighted on several occasions by the literature on knowledge transfer (see Cohen and Levinthal, 1989; Mangematin and Nesta, 1999) ${ }^{1}$. This paper aims at filling this gap by exploring the relationship among firm-level performance, absorptive capacity and types of knowledge; more specifically it suggests that firms adjust their learning strategies to fine-tune their capability to process and exploit external knowledge from the characteristics of the knowledge itself. According to this view, $\mathrm{R} \& \mathrm{D}$ intensive firms may develop learning strategies that allow them to process highly specialized technological knowledge sourced from firms that operate in a similar technological field while medium-tech industries may be specialized in sourcing knowledge from intermediate inputs or from their main competitors. If this is true, then the first group of firms will appear to benefit mostly from specialized knowledge while the opposite holds for the second group of firms. These considerations offer a straightforward way to test the hypothesis that firmlevel absorptive capacity is shaped by the knowledge firms are more likely to get exposure to. Indeed, the empirical literature on $R \& D$ spillovers suggests that absorptive capacity mediates the relationship between firm-level performance and R\&D spillovers. In addition, R\&D spillovers differ according to the types of knowledge they carry: pure (knowledge) spillovers tend to be

\footnotetext{
${ }^{1}$ Cohen and Levinthal (1989) suggested that the applicability and the complexity of the knowledge may influence the ability of a firm to absorb it. Equally, Mangematin and Nesta (1999) found more theoretical knowledge requires higher levels of absorptive capacity for the firm to be able to exploit it.
} 
carriers of technological knowledge contributing to innovation while rent spillovers are pecuniary externalities that travel along the supply chain (Griliches, 1979). This implies that if our hypothesis holds, then for the same level of observed absorptive capacity, firms located in areas (or economic environments) where pure knowledge spillovers are more important than rent spillovers may benefit more from the former type of spillovers than from the latter.

Our empirical strategy hinges on the notion that we can distinguish among different economic environments and prevailing types of knowledge flows in each area. Given the difficulty of doing so, we decide to operationalize this notion by focusing on economic areas that differ in their position with respect to the world technology frontier (Griffith et al., 2003; 2004). The assumption is that the distance from the frontier may capture different characteristics of the knowledge flows in an area. For instance, economic areas (or countries) that are closer to the frontier are characterized by sophisticated innovation ecosystems where research institutes and high-tech firms play a key role in producing the type of technological knowledge that is the building block of the pure R\&D spillovers. The implication is that in this type of environment pure spillovers matter for firm-level performance more than rent spillovers.

Empirically, we study how firm-level absorptive capacity mediates the relationship between rent and pure R\&D spillovers on the one hand and firm-level turnover on the other in three economic areas - Europe, Japan and US - which differ in their position with respect to the world technology frontier (Griffith et al., 2004). The analysis is conducted on a new dataset (sourced from the EU R\&D investment scoreboards) made of 879 R\&D-intensive manufacturing firms observed between 2002 and 2010. Empirically, we test our hypotheses by estimating a variety of augmented production functions for sub-set of firms located in each economic area covered by our dataset while controlling for the firm's absorptive capacity and for the different type of R\&D spillovers.

In line with the current literature, our R\&D spillovers have been computed as the amount of $\mathrm{R} \& \mathrm{D}$ conducted elsewhere weighted by a proxy for the intensity of knowledge flows between two firms. We use two measures of R\&D spillovers. The first measure is based on the methodology suggested by Jaffe (1986) and assumes that the closer two firms are in the technological space, the more the research activity of one firm is supposed to be affected by the technological spillovers generated by the research activities of the second firm. The second measure relies on the methodology of Terleckyj (1974) who suggested that the supply chain is the main transmission mechanism of R\&D spillovers. In both cases, we divide the potential stock of spillovers into two distinct components: intra-industry stock which corresponds to the sum of 
1 R\&D stocks of firms belonging to the same cluster of technological activities and an interindustry stock which is computed from the $\mathrm{R} \& \mathrm{D}$ conducted by firms belonging to other industries $^{2}$. The results suggest that for the same level of absorptive capacity, firms in economic areas that are closer to the world technology frontier tend to benefit more from pure (knowledge) spillovers than from rent spillovers. Vice versa, firms located in areas that are not on the technology frontier appear to benefit mostly from rent spillovers. These results suggest that firms tend to update and adapt their learning strategies so to better take advantage of the prevailing type of knowledge in the external environment.

This paper contributes to the existing literature on absorptive capacity in several ways: first, it shows that the nature of absorbed knowledge matters and that firms specialise in acquiring and processing specific types of knowledge. In general terms, we argue that the competencies needed by a firm in order to absorb external knowledge vary, depending on the nature of the knowledge consistently with what has been suggested in the field of organizational learning (see for instance Jansen et al., 2005). Second, it provides a potential explanation of why some firms appear to benefit from some types of spillovers more than from others and relates these differences to the characteristics of the absorbed knowledge. In itself, this is an interesting result as this is a gap in the literature on $R \& D$ spillovers as this has never engaged with such a research question. Finally, it provides some suggestive evidence on how the distance from the technology frontier influences firm-level absorptive capacity. There is a large literature that focuses on the distance from the technology frontier and its influence on firms' performance but very little is known about how it may potentially affect firm's internal strategies (see Griffith et al., 2004). This is one of the few papers that shows that country-level factors (like the distance from the frontier) may do exactly so in the context of the absorptive capacity.

The remainder of the paper is organized as follows. The next section briefly reviews the main literature on $\mathrm{R} \& \mathrm{D}$ spillovers and develops the main hypotheses. The data and empirical methodology are described in Section 3 while the results are discussed in Section 4. Finally, Section 5 offers some concluding remarks.

\section{Literature review and hypothesis development}

\footnotetext{
2 Intra-industry spillovers can be also be considered as specialized or Marshall-Arrow-Romer (MAR) spillovers (Marshall, 1890; Arrow, 1962; Romer, 1986), while inter-industry spillovers can be considered as diversified or Jacob spillovers (Jacobs, 1969).
} 
2 As mentioned in the Introduction, the literature on $R \& D$ externalities is rather voluminous as 3 knowledge accumulation has been for a long time recognized as a key driver of economic growth 4 Jones, 2002). The starting point of this literature is that knowledge generated by the investment in $\mathrm{R} \& \mathrm{D}$ can be considered equivalent to a public good as non-innovating firms can only be partially stopped from appropriating some of the benefits generated by the investment in R\&D.

7 This knowledge will then benefit the recipient firm as long as it helps to strengthen its competitive advantage in line with the Resource based view of a firm that considers knowledge a key resource contributing to the creation of its competitive advantage (Teece, 1992; Grant, 1996).

This literature has identified a variety of externalities that can be generated by the investment in R\&D. Griliches (1979) distinguishes between rent spillovers and pure knowledge spillovers. Rent spillovers arise when the prices of intermediate inputs purchased from other firms or countries are not fully adjusted for quality improvements resulting from the suppliers' R\&D investment with the result that some of the rents are appropriated by the users of the innovation (Terleckyj, 1974; Goto and Suzuki, 1989; Verspagen, 1997; Crespi et al., 2007). By contrast, pure knowledge spillovers arise because of the imperfect appropriability of ideas: the benefits of new knowledge accrue not only to the innovator, but "spill over" to other firms, thus enriching the pool of ideas subsequent innovations are based upon. In addition, the empirical literature on $R \& D$ spillovers has identified a variety of mechanisms that allow knowledge spillovers to travel across industries, regions and even countries with some authors highlighting the importance of intra-industry R\&D spillovers versus the inter-industry R\&D spillovers (see Kancs and Siliverstovs, 2016).

There are many channels through which knowledge produced by the investment in R\&D may leak out of a firm's boundaries. For instance, Grandstrand et al. (1992) point out that technical knowledge may leak thanks to the scanning efforts of the competitors. In addition, the literature on agglomeration economies suggests that knowledge may circulate among firms that share the same location thanks to the mobility of workers in the area (Fernandes and Ferreira, 2013; Hoetker amd Agarwal, 2007). Several studies have quantified the contribution of the R\&D spillovers to the firm-level TFP growth (Bernard and Jensen, 2004; Muûls and Pisu, 2007). In this context, it is customary to distinguish between the effects of horizontal (intra-industry) spillovers 
1 within the sector and vertical (inter-industry) spillovers across industries through local client and 2 supplier relations ${ }^{3}$.

3 Involuntary exposure to external knowledge does not necessarily imply that the recipient firm will 4 benefit from it in terms of enhanced performance or profitability. Indeed the channel through 5 which a firm gets exposure to external knowledge as well as the source of the knowledge will 6 determine whether it may benefit from it or not. There are many reasons for this. For instance, involuntary exposure to knowledge embodied in intermediate inputs may temporarily reduce the productivity of the recipient firm because it may make obsolete and redundant its existing products. Equally, knowledge embodied in new products developed by firms operating in the same industry may have a negative impact on the recipient firms' performance because of the potential market stealing effects (Kafouros and Buckley, 2008; Hall et al, 2009). Vice versa, external knowledge that is sourced from firms operating in similar technological areas tend to contribute positively to the performance of the recipient firm as the external knowledge may complement its existing competencies and offset the potential negative impact of external competition. This is particularly relevant to large firms that may have the broad competencies to benefit from external knowledge (Arora et al., 2001).

In this respect the firm's absorptive capacity plays an important role in mediating the relationship between the R\&D spillovers and firm level performance as the extent to which knowledge involuntarily acquired from other firms may benefit the recipient firm is really dependent on its capability to recognize and process external knowledge. This point is usually recognized by the literature on R\&D spillovers ${ }^{4}$ but not enough is understood about how the recipient firm's

\footnotetext{
3 As far as the horizontal spillovers are concerned, Globerman (1975) finds positive externalities in Canada. Driffield (2001) and Dimelis and Louri (2002) confirm the existence of intra-industry spillovers using data from UK and Greece respectively. Several studies show evidence of a positive relationship between the R\&D of 'technological neighbours' and the firm's R\&D productivity (Griffith, Harrison and Van Reenen, 2006). In terms of impact on firms' productivity, the effects of R\&D spillovers also appear to be mainly technologically localised (Jaffe 1986, 1988). Following this line of research, Lychagin, Pinkse, Slade and Van Reenen (2010) assess the contributions to productivity of three sources of research and development spillovers: geographic, technology and product-market proximity. To do this, they construct a new measure of geographic proximity that is based on the distribution of a firm's inventor locations rather than its headquarters (as in Aldieri and Vinci, 2016a). In order to analyse the relationship between R\&D spillovers and productivity, O'Mahony and Vecchi (2009) and Aldieri and Vinci (2016b) consider a different instrument of technological proximity. Indeed, they sort the industries into two categories: factor and skill intensive groups, which account for differences in the knowledge intensity and innovative activities within sectors. The results provide evidence of higher productivity in R\&D and skill intensive industries and this can be interpreted as evidence in favour of the presence of spillover effects.

${ }^{4}$ Several authors point out that knowledge and technology flows are strongly dampened by geographical distance (Keller (2002), Maurseth and Verspagen (2002) and Jaffe, Trajtenberg and Henderson (1993) with
} 
1 absorptive capacity really works. First introduced by Cohen and Levinthal (1990), its central tenet

2 is that the firm's capacity to absorb and utilise external knowledge is strongly related to its

3 willingness to invest in specific strategies that allow them to identify external knowledge and use

4 it for its own purpose. Our understanding of the concept of absorptive capacity has been shaped

5 by the work of Cohen and Levinthal (1989) as well as of Zahra and George (2002). Cohen and

6 Levinthal (1989) defined absorptive capacity as the ability of a firm 'to recognize the value of new

7 information, assimilate it, and apply it to commercial ends' (Cohen and Levinthal 1990, 128) and

8 suggested these are connected to the learning capability of the firm. Subsequently, absorptive capacity has been reconceptualised as a dynamic capability - see Zahra and George, 2002 and the subsequent paper by Todorova and Durisin (2007) - which emphasizes the processes and learning routines of the firm (see also Jansen et al. 2005). Zahra and George (2002) suggest there are four dimensions to the absorptive capability: acquisition, assimilation, transformation and exploitation ${ }^{5}$. An interesting aspect of the view of absorptive capacity as a set of learning routines is that these tend to be influenced by the external environment. Van den Bosch et al. (1999) were the first to suggest that the firm's knowledge environment could influence the development of its absorptive capacity. They found that the degree of competition a firm faces also affect its absorptive capacity and ultimately its capability of processing external information. More specifically they found that depending on the nature of external competition, firms adopt different mechanisms to accumulate knowledge. Along the same lines, Makinen and Vilkko (2014) studied how absorptive capacity can vary with an unstable external environment.

An aspect that has not been explored enough by the literature on absorptive capacity is the nature of the knowledge being absorbed, which is a key part of the absorptive capacity process. Indeed, we would expect that external knowledge with a greater degree of overlap with existing knowledge can be easily exploited by a firm. Some authors have pointed out the importance of knowledge attributes in this context. For instance, Hansen (1999) suggested that the complexity of the technological knowledge matters for its absorption. Similarly, Mangematin and Nesta (1999) found that the less applied knowledge is, the higher the level absorptive capacity required by the firm to exploit it ${ }^{6}$. There are other aspects of knowledge that may be of relevance in this

the result that more resources are required to enable learning from R\&D activities that are undertaken far away in terms of geographical distance.

5 Acquisition refers to a firm's capability to identify and acquire external knowledge while assimilation refers to the firm's routines and processes that allow it to process it. Transformation refers to the firm's capability to develop the routines that support the combination of existing knowledge with external knowledge while exploitation refers to the firm's ability to use new knowledge for commercial use.

${ }^{6}$ See also the contribution of Lane and Lubatkin (1998) and Dyer and Singh (1998) who question the 
context. Some authors distinguish two types of knowledge (see for instance Cassiman and

2 Veugelers, 2000): the first one focuses on technology at user level and/or on business trends

3 while the second one allows a firm to integrate complex external knowledge into its processes.

$4 \quad$ We argue that the first type of knowledge will be easier to exploit than the second one because it

5 requires less technological expertise for its exploitation. In practice, this type of knowledge is mostly obtained from the supply chain from sources such as suppliers or customers. However, while customers can contribute to the creation of a very specific innovation (von Hippel, 1988), their knowledge may not be that innovative (Siegel, 2004; Link et al., 2006) compared to the knowledge produced by universities or research centres (Dussauge et al., 2000). So if the firm belongs to an industry where innovation depends on the knowledge generated by customers or suppliers, then it may have to adapt its learning strategies so that it can recognise and process external knowledge which may not be too novel or path-breaking and is sourced mostly from market inputs. In contrast, the second type of knowledge is more difficult to acquire and exploit. Sources of this type of knowledge include universities and other high tech firms. If this type of knowledge is important to support innovation, then the firm will need to develop the capabilities to access this technological knowledge and exploit it. In these cases, their learning strategies will differ from those that are adopted by firms that rely on knowledge acquired from the supply chain (Laursen and Salter, 2006).

The type of knowledge a firm is more likely to get exposure to affects also the direction of its external knowledge search efforts (Szulanski, 1996). For instance, a firm may tend to use the same sources of external knowledge used before and ignore new sources. Fosfuri and Tribò (2008) suggest that firms whose research staff are not research active may not consider it as a source of external knowledge. All this makes absorptive capacity path dependent and locks firms in specific search strategies.

These considerations imply that firms specialise in acquiring and benefit from specific types of knowledge. For instance firms operating in environments with sophisticated innovation ecosystems tend to specialise learning strategies that allow them to benefit from the specialised knowledge they are more likely to produce. In terms of empirically testable hypotheses, at a firm level we should observe that similar firms with similar levels of observed absorptive capacity may

assumption that a firm has equal capacity to absorb knowledge from any other firm. Also, it has been shown that absorptive capacity is negatively correlated with cognitive distance (Nooteboom et al., 2007) where cognitive distance measures how far apart the knowledge bases of two firms are. 
still benefit from different types of external knowledge (which can be embodied in the two types of R\&D spillovers) and this variability can be related to the characteristics of the firms' external environment. We assume that pure $\mathrm{R} \& \mathrm{D}$ spillovers are proxies for scientific and highly technical knowledge while rent spillovers proxy for knowledge acquired along the supply chain. Assuming that these two proxies are valid and that the distance from the technology frontier summarises the characteristics of the knowledge flows in an area (or a country), we can then argue that:

H1: Firms located in countries that are closer to the technology frontier benefit more from pure $R \& D$ spillovers than from rent $R \& D$ spillovers for the same level of observed absorptive capacity.

\section{Conversely:}

H2: Firms located in countries that are further from the technology frontier benefit more from rent R\&D spillovers than from pure R\&D spillovers for the same level of observed absorptive capacity.

The remainder of the paper will focus on the empirical testing of these two hypotheses.

\section{Empirical framework}

\subsection{Data and variables}

For our empirical analysis, we employ the same data sources as in Aldieri and Vinci (2016a). The main data sources are the EU R\&D investment scoreboards that have been issued by the JRCIPTS between 2002 and 2010 (European Commission, 2011). It covers firms that are located in all countries in the world and is constructed in such a way that it is representative of the largest worldwide firms that report R\&D expenditure. For each firm, the scoreboard reports data on net sales (S), number of employees (L), annual capital expenditure $(\mathrm{C})$, annual R\&D expenditure (K) as well as the two-digit industrial sector according to the Industrial Classification Benchmark (ICB). The second database we use for this paper is REGPAT (January 2012 ${ }^{7,8}$ ) which is issued by the OECD. REGPAT collects data on patents and allocates them to each country according to the addresses of the applicant and inventors. For each patent, REGPAT has information on the backward and forward citations as well as their technical field. In addition, it has information

\footnotetext{
7 See Maraut S., H. Dernis, C. Webb, V. Spieazia and D. Guellec (2008) for the methodology used for the construction of REGPAT.

8 Please contact Helene.DERNIS@,oecd.org to download the REGPAT database.
} 
on the patent holder's main characteristics (i.e. whether a company or an individual and the industrial sector in case of a company). From REGPAT, we have selected the addresses of the applicant and of the inventor as well as the patent's technological field and matched the firms in the R\&D scoreboard with their counterparts in the REGPAT database using a manual matching procedure as described in Aldieri and Vinci (2016a).

Monetary values have been converted into Euros with 2007 being the reference year ${ }^{9}$. Data from the R\&D scoreboards are already expressed in Euros and annual scoreboards use a fixed exchange rate for each currency to convert data into Euros. Therefore, first we have converted the monetary data into their original currencies by using the exchange rate specific to each scoreboard. Second, the newly converted variables have been converted into Euros using a fixed exchange rate ${ }^{10}$. Data have been deflated ${ }^{11}$ by using national GDP price deflators where 2007 appears as the reference year. The $\mathrm{R} \& \mathrm{D}$ and physical capital stocks are constructed by using a perpetual inventory method (Griliches, 1979) with a depreciation rate of 0.15 for the R\&D capital stock and 0.08 for the physical capital stock as usually assumed in the relevant literature. Observations with missing values have been removed and all observations for which the R\&D intensity (defined as the R\&D investments divided by the firm's net sales) is below $0.1 \%$ or above $100 \%$ have been deleted. As a result we have removed 5 firms below the first threshold (mainly firms from the retail and travel and leisure industry sectors) and 25 firms above the second threshold (firms mainly in the pharmaceuticals sector ${ }^{12}$ ). This leads to an unbalanced panel of 838 firms observed over the period 2002-2010. Table 1 provides an overview of the sample by industry and geography. In the table, we sort industries into High-, Medium- and Low-tech industries according to their R\&D intensity. Low-tech firms have a $R \& D$ intensity below $2 \%$, Medium-tech firms have a R\&D intensity between $2 \%$ and $5 \%$ while High-tech firms have a $\mathrm{R} \& \mathrm{D}$ intensity above $5 \%$. The US-based firms are the ones with the highest R\&D intensity followed by Japan and finally Europe. These figures are broadly in line with similar indicators reported by Griffith et al. (2004) and suggest that US firms are closer to the world technology frontier than Japanese and European firms ${ }^{13}$. In terms of sectorial mix, both services and manufacturing are represented in our sample.

\footnotetext{
${ }^{9}$ Source of the exchange rates and deflators is EUROSTAT.

${ }^{10}$ We use the exchange rates for 2007.

${ }^{11}$ Eurostat GDP deflators.

12 These firms are research laboratories which work only in R\&D. Sales are very limited and this explains the very high $R \& D$ intensity, i. e. above $100 \%$.

${ }^{13}$ See Griffith et al. (2004) for similar remarks.
} 


Economic Area/ R\&D

3 Sectors Intensity $^{\mathrm{b}}$

Europe $^{\mathrm{a}}$

Japan

USA

\section{Low-tech}

Construction

materials

Food \& Beverage

Telecommunications

Utilities

Banking

\section{Medium-tech}

Automotive

components

Industrial goods \&

services

Chemicals

Personal \& household

goods

$\&$

Media

Retail

Travel \& leisure

\section{High-tech}

Health care 16.8

Technology
3.8

4

6.3

5 a: R\&D intensity $=\mathrm{R} \& \mathrm{D}$ expenditures/net sales (in \%)

6 b: Austria, Belgium, Denmark, Finland, France, Germany, Ireland, Italy, Luxembourg, Spain, 7 Sweden, The Netherlands and the United Kingdom 
2

3 A key issue in any empirical analysis of R\&D spillovers is the measurement of the pool of

\subsection{Constructing the pool of external knowledge} external knowledge generated by the investment in $\mathrm{R} \& \mathrm{D}$. This pool is usually computed as the amount of $R \& D$ conducted elsewhere weighted by some measure of proximity, which reflects the intensity of the knowledge flows between the source and the recipient of spillovers ${ }^{14}$. As mentioned in the literature review, it is customary to distinguish between knowledge spillovers and rent spillovers. Theoretically, the distinction between the two concepts of spillovers seems clear, but their empirical identification is rather complex. In this paper, we implement two procedures to identify the spillovers: one based on patent data (Jaffe's measure) and one based on trade shares between sectors of different countries. From previous discussions in the literature, we assume that spillovers computed using the Jaffe methodology are 'knowledge' spillovers, while the ones calculated from trade shares flows are 'rent' spillovers that travel along the supply chain.

The Jaffe's methodology (1986) assumes that while technological knowledge is available to all firms, only firms that are technologically similar to the source of the spillovers can really benefit from them. This procedure rests on the construction of a technological vector for each firm based on the distribution of its patents across technology classes ${ }^{15}$. These vectors allow to locate firms into a multi-dimensional technological space where technological proximities between firms are performed as the uncentered correlation coefficient between the corresponding technology vectors:

$$
P_{i j}=\frac{\sum_{k=1}^{K} T_{i k} T_{j k}}{\sqrt{\sum_{k=1}^{K} T_{i k}^{2} \sum_{k=1}^{K} T_{j k}^{2}}}
$$

14 See Griliches (1992), Mohnen (1996) or Cincera and Van Pottelsberghe (2001) for a review of the different proximity measures used in the literature.

15118 technological classes make up the International Patent Classification (IPC) at the two-digit level. In order to ease the calculations, these 118 classes are grouped into broader classes. On this basis, a table of contingency, i. e. a table reporting the distribution of the firms' patents across the 50 IPC classes, is constructed as in Cincera (1998). This table is used to compute the index of technological closeness and then the stocks of spillovers. 
1 The technological proximity index is then used to compute the total weighted stock of R\&D

2 spillovers as follows:

3

$4 \quad T S_{i}=\sum_{i \neq j} P_{i j} K_{j}$

5

6 where $K_{j}$ is the R\&D capital stock of firm $j$ (as in Aldieri and Cincera, 2009).

7 The second measure relies on the methodology of Terleckyj (1974) who suggested to use inputoutput data to measure the inter-industry flows of technologies. The assumption behind this approach to the measurement of spillovers is that the more industry $i$ acquires from and sells to industry $j$, the more it can be influenced by industry $j$ (Audretsch and Feldman,1996; Peri, 2005; Piga and Poyago-Theotoky, 2005; Carboni, 2013). We therefore create a distance matrix based on a measure of trade intensity between sectors derived from the input-output matrix ${ }^{16}$ for the firms in our sample (Carboni, 2013). Weights are proportional to the inter-industry trade flows (Wolff and Nadiri, 1993). Each element of the distance matrix (wij), is defined as the average of the bilateral input-shares between sectors $i$ and $j$ (Coe and Helpman, 1995) and represents the intensity of the relation between these two industries in each country. The indicators have been calculated on the basis of a Leontief inverse, computed by using the World Input-Output Tables (as in Higon and Sena, 2014). The elements of the symmetric spatial matrix are calculated as:

$w=\frac{z_{i j}+z_{j i}}{2}$

where $i \neq j$, $z_{i j}$ are the bilateral input-shares of sector $i$ from sector $j$ and $i=j$, $z_{i j}$ are the bilateral input-shares within the same sector.

\subsection{Measuring absorptive capacity}

Traditionally, the absorptive capacity of a firm is proxied by the firm-level R\&D intensity under the assumption that firms can fully appropriate the benefits of its investment in R\&D (Cohen and Levinthal, 1989; Kinoshita, 2000; Grunfeld, 2004; Giovannetti and Piga, 2017). However, this measure of absorptive capacity does only capture the input to the production of innovation but not the actual learning that takes place in the firm following the investment in R\&D. In

\footnotetext{
${ }^{16}$ Data are available at www.wiod.org.
} 
1 addition, such a measure does not capture the fact that firms may vary in their capability of

2 processing highly technical knowledge. For these reasons, we employ two different measures of

3 absorptive capacity. The first one is the stock of R\&D which captures the cumulative nature of

4 the learning process (Griffith et al., 2003; Aldieri and Cincera, 2009). The second measure is the

5 percentage of self-citations i.e. the percentage of citations of patents issued by the same assignee

6 (Mancusi, 2008). If a firm cites its own patents in the application for a new patent, this is the best

7 indicator of the fact that a firm did some research in a technological field in the past that has

8 generated a patentable innovation. The new measure captures the extent to which the firm has

9 developed the capability of processing and exploiting technological knowledge to generate a

10 patentable innovation.

12 Table 2 presents the summary statistics for the main variables in our sample. These are the net 13 sales in $\log$ terms $(\mathrm{LnS})$, number of employees in log terms $(\mathrm{LnL})$, physical capital in log terms 14 ( $\mathrm{LnC}), \mathrm{R} \& \mathrm{D}$ capital stock in $\log$ terms $(\mathrm{LnK}), \log$ of the total stock of spillovers calculated using 15 the Jaffe's methodology (LnTS), the total stock of spillovers based on bilateral trade shares 16 between the industries (Ln'TradeTot) and the number of self citations (Self).

\begin{tabular}{l|l|l} 
Variable & Mean & Std. Dev. \\
\hline Net Sales $\left(\mathrm{S}_{\text {iszt }}\right)$ & 8.02 & 1.646 \\
\hline Labour $\left(\mathrm{L}_{\text {iszt }}\right)$ & 9.46 & 1.552 \\
\hline Physical Capital $\left(\mathrm{C}_{\text {iszz }}\right)$ & 7.04 & 1.462 \\
\hline R\&D Capital Stock $\left(\mathrm{K}_{\text {iszt }}\right)$ & 6.58 & 0.430 \\
\hline $\begin{array}{l}\text { Knowledge Spillovers Total } \\
\text { Stock }\left(\mathrm{TS}_{\text {iszt }}\right)\end{array}$ & 12.89 & 1.627 \\
\hline $\begin{array}{l}\text { Rent Spillovers Total Stock } \\
\text { (TradeTot }\end{array}$ szt & & 3611.38 \\
\hline Number of Self-Citations & 742.78 &
\end{tabular}




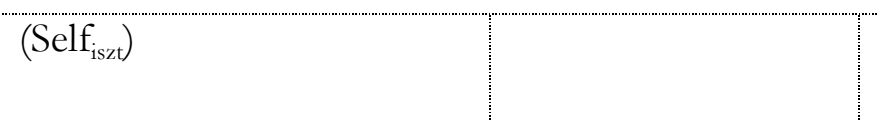

1

2

3 Figure 1 shows the distribution of the percentage of self-citations by economic area. The lowest

4 number of self-citations is in Europe while Japanese firms have the largest share of self-citations

5 in our sample.

6 Figure 1. Distribution of self-citations by geographical area

7

9

10

11

12

13

14

15

16

17

18

Note: Authors' calculations. 5857 observations.

\section{Figure 1. Distribution of self-citations by geographical area}

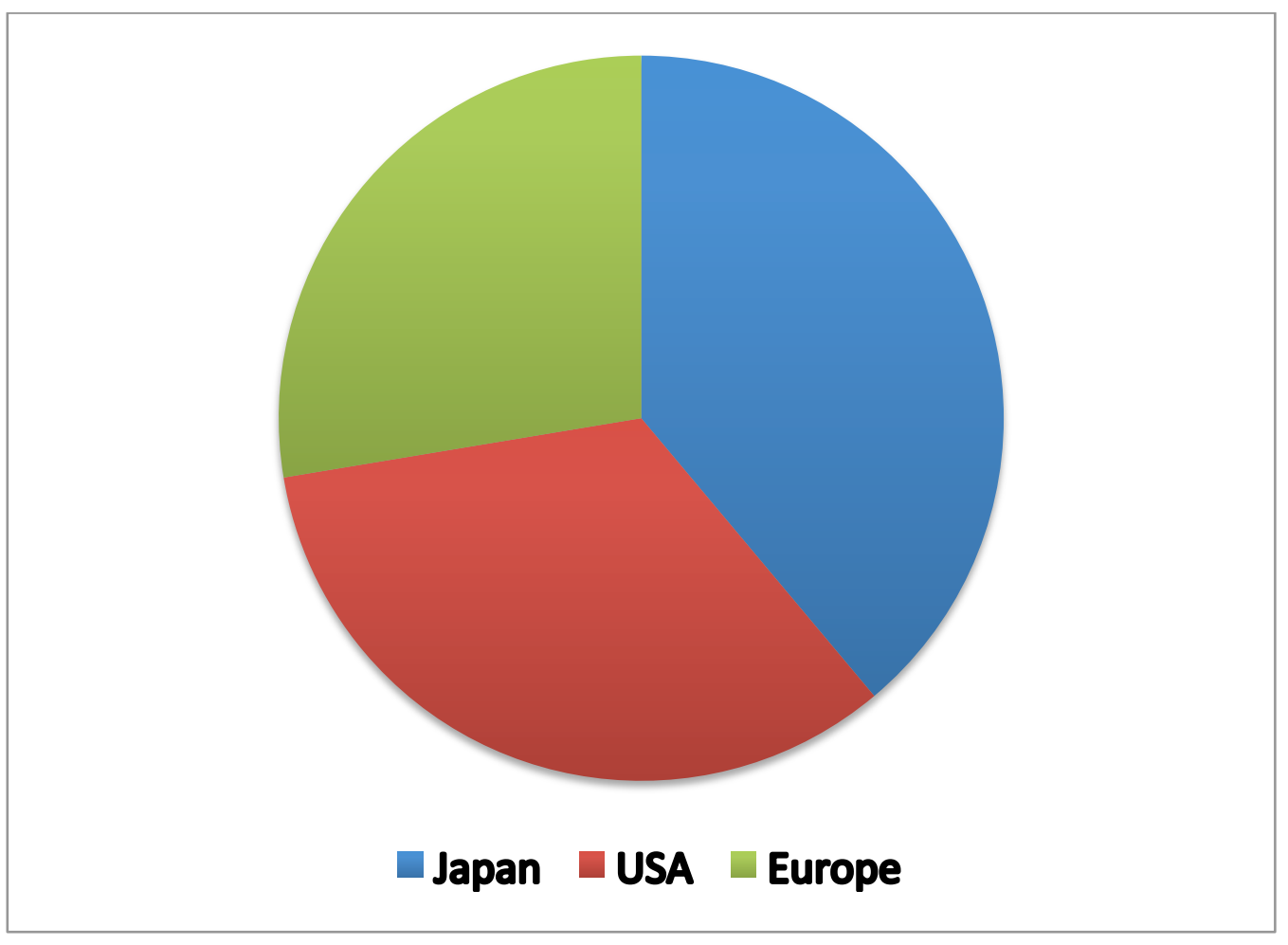
(1)

\subsection{Econometric framework}

As in Griliches (1979), the impact of the R\&D spillovers on firm-level performance is estimated by an augmented Cobb-Douglas production function:

$$
Y=A L^{\beta_{1}} C^{\beta_{2}} K^{\beta_{3}} X^{\gamma}(4)
$$

8 Taking the logarithms of (4) and adding a set of time/country/sectorial dummies we get: 
$2 \quad \ln Y_{i s z t}=\alpha_{i}+\delta_{s}+\theta_{z}+\lambda_{t}+\beta_{1} \ln L_{i s z t}+\beta_{2} \ln C_{i s z t}+\beta_{3} \ln K_{i s z t}+\gamma \ln X_{s z t}+\varepsilon_{i s z t}(5)$

3

4 Where $\ln$ is the natural logarithm, $Y_{i t s z}$ is the net sales, $L_{i t s z}$ is the number of employees, $C_{i t s z}$ is

5 the physical capital stock, $K_{i t s z}$ is the R\&D capital stock, $\alpha_{i}$ are the firm's fixed effect, $\delta_{\mathrm{s}}$ is a set

6 of industry sector dummies, $\theta_{z}$ is a set of country dummies, $\lambda_{t}$ is a set of time dummies, $X_{s z t}$ is

7 the vector of spillover variables, $\beta$ and $\gamma$ are the parameters to estimate and $\varepsilon_{i t s z}$ is the

8 disturbance term. Because of data unavailability, we do not include raw materials in our equation

9 and while this may result into a set of estimated coefficients whose magnitude differs from what other studies have found, sign and significance should be the same as discussed in Aldieri and Cincera (2009) and O’Mahony and Vecchi (2009).

We consider six alternative specifications of the spillover variables. In the first specification, the spillover variable is measured as:

$\gamma \ln X_{\mathrm{szt}}=\gamma \ln$ Tradetot $_{\mathrm{szt}}(7)$

where TS the total stock of spillovers computed from (2) and Tradetot is the total stock of spillovers where the weights are calculated as in (3).

The second specification assumes that the R\&D spillovers can be split between intra- and interindustry spillovers:

$\gamma \ln X_{i s z t}=\gamma_{I N T R A S} \ln \operatorname{IntraS} S_{\text {iszt }}+\gamma_{\text {INTERS }} \ln \operatorname{InterS} S_{\text {iszt }}(8)$

where IntraS and InterS are calculated using the Jaffe procedure. In particular, IntraS is the weighted sum of the R\&D expenditure of the firms belonging to the same two-digit industry as the recipient firm while InterS considers the total R\&D expenditure of firms belonging to all other industries.

$$
\gamma \ln X_{\mathrm{szt}}=\gamma_{\text {INTRAS }} \ln \text { TradeIntraS } S_{\mathrm{szt}}+\gamma_{\text {INTERS }} \ln \text { TradeInter } S_{\mathrm{szt}}(9)
$$


1 where Tradeintra and Tradeinter are the intra- and inter-industry stocks of spillovers

2 calculated along the supply chain.

3

4 In another set of empirical specifications of the augmented production function, we assume that 5 the elasticity of output to the stock of spillovers is conditional on the firm's absorptive capacity.

6 Therefore, we have interacted the firm's own R\&D capital and the R\&D spillover stock (Aldieri 7 and Cincera, 2009): $K_{i s 2} \ln X_{s i t}$

In an additional specification, we have interacted the number of self-citations with each of the $\mathrm{R} \& \mathrm{D}$ spillover variables as a robustness test: $\operatorname{Self}_{i s i t} \ln X_{\text {sit: }}$.

$\ln Y_{i s z t}=a_{i}+\delta_{s}+\theta_{z}+\lambda_{t}+\beta_{1} \ln L_{i s z t}+\beta_{2} \ln C_{i s z t}+\beta_{3} \ln K_{i s z t}+\gamma \ln X_{s z t}+\omega K_{i s z t} \operatorname{Self}_{i s z t}+\epsilon_{i s z t}$

To estimate equations (5) and (10), we use the standard panel data estimation procedures that control for firm-level heterogeneity. The fixed effects can be removed through the so-called Within Groups (WG) transformation which can be estimated by OLS provided that $\alpha_{i}$ are fixed over time and the regressors are strictly exogenous. Another way to eliminate the unobserved fixed effects is by first-differencing the augmented production function. An advantage of this transformation is that it does not longer require the strict exogeneity of regressors. However, because of the potential measurement errors in the variables, this procedure leads generally to estimates which are more biased towards zero than the within correction. For this reason, we use the System Generalized Method of Moments (Sys-GMM) ${ }^{17}$ estimator, which combines the standard set of equations in first difference with suitably lagged levels as instruments (DiffGMM), with an additional set of equations in levels with suitably lagged first differences as instruments. The validity of these additional instruments, which consist of first difference lagged values of the regressors, can be tested through the difference Sargan over-identification tests. Finally SYS-GMM takes into account the possible endogeneity or simultaneity issue of the explanatory variables with the error term.

\section{Empirical findings}

\footnotetext{
${ }^{17}$ See Arellano and Bover (1995), Blundell and Bond (1998).
} 
2 This section summarises the results of our empirical analysis. Section 4.1 comments on the 3 estimates of equation (5) while the results of equations (10) - our main empirical results - are commented in Section 4.2. The first set of results can be considered preliminary as they do not focus on absorptive capacity and its role in mediating the relationship between performance and $\mathrm{R} \& \mathrm{D}$ spillovers. Still these results provide useful information on the quality of our empirical specifications as well as early insights on how firm-level performance is influenced by different types of R\&D spillovers.

\subsection{Preliminary results}

Tables 3-4 report the estimated production function (augmented with the different specifications of the spillovers) for the whole sample using the two estimators, the Within-Group ${ }^{18}$ (WG) and the Sys-GMM while Tables 5-6 present the results from the estimation of similar empirical specifications for each of the three economic areas in our sample ${ }^{19}$. In both cases, the first two panels report estimates of the production functions augmented by the $R \& D$ spillovers calculated using the Jaffe procedure while the last two panels report equivalent estimates where the trade spillovers are now included. We control for both time, sector and country dummies while the standard errors are clustered around the firm and the year.

In terms of the diagnostics, the two tests on the serial correlation of the first-differenced residuals are consistent with the hypothesis of no serial correlation in the residuals in levels ${ }^{20}$. The Sargan test rejects the null hypothesis of valid instruments, indicating that some of the instruments in our sample are correlated with the error term. However, it is established that the Sargan test tends to over-reject the null hypothesis in equations specified in first-differences (Blundell and Bond, 1998) and therefore as in O’Mahony and Vecchi (2009) we still prefer the Sys-GMM estimates to the WG ones.

Table 3 Augmented Production Function Estimates - Total R\&DD Spillovers

\footnotetext{
${ }^{18}$ The Hausman's test has been used to test fixed effects versus random effects model. The results suggest that the fixed effects estimator has to be preferred to the random effects one.

19 See Capron and Cincera (1998), Aldieri and Cincera (2009) for other applications of Sys-GMM estimator to R\&D technological spillovers.

${ }^{20}$ The assumption of no serial correlation in the residuals in levels is very important to obtain consistent GMM estimates. This assumption holds if there is evidence of significant and negative first-order serial correlation and no evidence of second-order serial correlation in the first-differenced residuals (Arellano and Bond, 1991).
} 
Est.

S. E.

\section{JAFFE's \\ procedure}

$\begin{array}{llllll}\mathrm{LnL} & 0.68^{* * *}(0.014) & \Delta \ln \mathrm{C} & 0.56^{* * *} & (0.033) \\ \ln \mathrm{C} & 0.22^{* * *}(0.017) & \Delta \ln \mathrm{C} & 0.26^{* * *} & (0.073) \\ \ln \mathrm{K} & 0.15^{* * *}(0.016) & \Delta \ln \mathrm{K} & 0.10 & (0.107) \\ \ln \mathrm{TS} & 0.79^{* * *} & (0.073) & \Delta \ln \mathrm{TS} & 0.77^{* * *} & (0.130)\end{array}$

$\begin{array}{llll} & & & \\ & \operatorname{AR}(1)^{c} \text { test } & \mathrm{p}=-9.03 & \mathrm{p}>\mathrm{z}=0.000 \\ & \operatorname{AR}(2) \text { test } & \mathrm{p}=-1.07 & \mathrm{p}>\mathrm{z}=0.285 \\ \operatorname{Sargan}^{\mathrm{b}}: \chi^{2} & & \\ \mathrm{R}^{2} & (78)=382.49 & & {[0.000]}\end{array}$

4 TRADE Intensity Procedure

$\begin{array}{llllll}\operatorname{LnL} & 0.67^{* * *} & (0.014) & \Delta \ln \mathrm{L} & 0.56^{* * *} & (0.036) \\ \ln \mathrm{C} & 0.21^{* * *} & (0.017) & \Delta \ln \mathrm{C} & 0.24^{* * *} & (0.061) \\ \ln \mathrm{K} & 0.18^{* * *} & (0.016) & \Delta \ln \mathrm{K} & 0.16^{* * *} & (0.053) \\ \ln \text { Tradetot } & 0.01^{*} & (0.004) & \Delta \ln \text { Tradetot } & 0.00 & (0.005) \\ & & & \operatorname{AR}(1)^{\mathrm{c}} \text { test } & \mathrm{p}=-8.99 & \mathrm{p}>\mathrm{z}=0.000 \\ & & & \operatorname{AR}(2) \text { test } & \mathrm{p}=-1.43 & \mathrm{p}>\mathrm{z}=0.153 \\ & & & \operatorname{Sargan}^{\mathrm{b}}: \chi^{2} & & \\ \mathrm{R}^{2} & & & (80)=177.75 & & {[0.000]}\end{array}$

a: heteroskedastic-consistent standard errors, which are clustered around the firm and the year. b: Sargan is the Sargan-test of over identifying restrictions, the p-value is in squared brackets. c: $\operatorname{AR}(1)$ and $\operatorname{AR}(2)$ are tests for first and second order serial correlation. ***,**, * Coefficient significant at the 1\%,5\%,10\%. Country, Sector and Time dummies are included.

The coefficients of labour and capital are both significant. The estimated elasticity of labour is 0.56 in both specifications while in the case of capital the coefficients range between 0.24 and 0.26. The coefficient associated to the R\&D capital is not significant in the specification where 14 we control for the Jaffe-based R\&D spillovers while it is in the other specification. These results tend to be rather standard when estimating augmented production functions because of the 
1 potential multicollinearity between the firm-level R\&D stock and the industry-level R\&D 2 spillovers.

3

4 Our benchmark results show the firm-level performance is significantly influenced by knowledge 5 spillovers but not by rent spillovers. Indeed the estimated elasticity of the total stock of 6 knowledge spillovers (TS) is 0.77 while rent spillovers are not significant in our sample (see the 7 last two panels of Table 3). These results are qualitatively in line with the existing literature: 8 indeed knowledge spillovers are typically found to be beneficial to firms as they provide new 9 knowledge which contributes to the firm's innovation performance unlike rent spillovers (see 10 Section 2 for a discussion on the expected contribution of rent spillovers to firm-level 11 performance).

12

\section{JAFFE's}

\section{procedure}

$\Delta \ln \mathrm{L}$

$\Delta \ln C$

$\Delta \ln K$

$\Delta$ lnintraS

$\Delta$ lninterS

AR(1) test

$\operatorname{AR}(2)$ test

Sargan

$\mathrm{R}^{2}$

0.61

$\chi^{2}(97)=415.09$

$0.57 * * *$

(0.033)

Est.

S. E.

\begin{tabular}{|c|c|c|c|c|}
\hline $\ln \mathrm{L}$ & $0.66^{* * *} \quad(0.014)$ & $\Delta \ln \mathrm{L}$ & $0.55^{* * *}$ & $(0.036)$ \\
\hline $\ln C$ & $0.21 * * * \quad(0.017)$ & $\Delta \ln C$ & $0.25^{* * *}$ & $(0.057)$ \\
\hline $\ln K$ & $0.18^{* * *}(0.016)$ & $\Delta \ln K$ & $0.16^{* * *}$ & $(0.051)$ \\
\hline
\end{tabular}




$\begin{array}{llllll}\ln \text { Tradeintra } & 0.00 & (0.001) & \Delta \ln \text { Tradeintra } & -0.01 * * * & (0.001) \\ \ln \text { Tradeinter } & -0.01^{* *} & (0.003) & \Delta \ln \text { Tradeinter } & 0.00 & (0.005) \\ & & & \operatorname{AR}(1) \text { test } & \mathrm{p}=-9.60 & \mathrm{p}>\mathrm{z}=0.000 \\ & & & \mathrm{AR}(2) \text { test } & \mathrm{p}=-1.73 & \mathrm{p}>\mathrm{z}=0.084 \\ \mathrm{R}^{2} & 0.61 & \text { Sargan }:^{2}(100)=217.53 & {[0.000]}\end{array}$

3

a: heteroskedastic-consistent standard errors, which are clustered around the firm and the year. b: Sargan is the Sargan-test of over identifying restrictions, the p-value is in squared brackets. c: $\operatorname{AR}(1)$ and $\operatorname{AR}(2)$ are tests for first and second order serial correlation. $* * * * *, *$ Coefficient significant at the 1\%,5\%,10\%. Country, Sector and Time dummies are included.

Once we distinguish between intra- and inter-industries R\&D spillovers (Table 4), there are more interesting insights on the relative contribution of the different types of spillovers to firm-level performance. Indeed, the results show that in the case of knowledge spillovers, inter-industry spillovers are much more important than intra-industry spillovers that are now not significant (see Capron and Cincera (1998) for a similar result). This implies that Jacobian externalities are much more important than Marshallian externalities (van der Panne, 2004; Autant-Bernard et al., 2011). Also, the negative effects of the rent spillovers performance are driven by the intraindustry spillovers that tend to be significant but with a negative coefficient. This is hardly surprising as we would expect that the competitive effects will be stronger among firms that belong to the same industry (see discussion in Section 2).

In Tables 5 and 6, we present the estimates of similar specifications of the augmented production functions where firms in our sample have now been sorted by their location. More specifically, the first panel refers to US-based firms while the second and third panels refer to Japan- and EUbased firms respectively. Table 5 refers to the R\&D-based spillovers while Table 6 refers to the rent spillovers. In both cases, the serial correlation tests do not reject the hypothesis of no serial correlation in the residuals in levels. As for the spillover variables, firms based in the US tend to benefit mostly from intra-industry R\&D spillovers in line with what other studies find (Orlando, 2004; Bloom, Schankerman and Van Reenen, 2013) while the opposite is true for EU-based firms, which benefit mostly from inter-industry R\&D spillovers ${ }^{21}$. Aldieri and Cincera (2009) show that US firms are mainly sensitive to spillover effects generated by other R\&D intensive domestic firms while European firms appear to mainly benefit from the inter-industry $R \& D$ spillovers. These results suggest that firms have specialised search strategies with US firms mostly

21 According to Iršová and Havránek (2013) the sign and magnitude of horizontal spillovers depend on the characteristics of the domestic economy. 
1 exploiting knowledge produced directly by their competitors while European firms have

2 developed broad competencies that allows them to extract and exploit knowledge from a variety

3 of industries. The results for Japan are also rather telling: knowledge spillovers do not appear to

4 contribute to firm-level performance in our sample. This result is in line with the findings of

5 Ikeuchi et al. (2013) who point out that the importance of inter-industry spillovers to foster

6 innovation among Japanese firms has diminished over time as the number of firms exiting the

7 market has increased substantially from 2000 onwards. As for the rent spillovers, these tend to be

8 negatively correlated with performance for each sub-set of firms although they are significant

9 only for the sample of Japanese firms.

10

Table 5. Augmented Production Function Estimates by Geographical Area (JAFFE's procedure)

S. $E^{a}$.

Est.

S. E.

\begin{tabular}{|c|c|c|c|c|c|}
\hline $\ln \mathrm{L}$ & $0.69 * * *$ & $(0.025)$ & $\Delta \ln \mathrm{L}$ & $0.54 * * *$ & $(0.048)$ \\
\hline $\ln C$ & $0.26 * * *$ & $(0.029)$ & $\Delta \ln C$ & $0.27 * *$ & $(0.131)$ \\
\hline $\ln K$ & $0.19 * * *$ & $(0.035)$ & $\Delta \ln K$ & 0.25 & $(0.153)$ \\
\hline lnintraS & $0.38^{* * *}$ & $(0.058)$ & $\Delta \operatorname{lnintraS}$ & $0.16^{* * *}$ & $(0.069)$ \\
\hline \multirow[t]{3}{*}{ lninterS } & $0.48^{* * *}$ & $(0.175)$ & $\Delta \operatorname{lninterS}$ & 0.12 & $(0.276)$ \\
\hline & & & $\operatorname{AR}(1)^{c}$ test & $\mathrm{p}=-6.58$ & $\mathrm{p}>_{\mathrm{z}}=0.000$ \\
\hline & & & $\mathrm{AR}(2)$ test & $p=-0.66$ & $\mathrm{p}>_{\mathrm{z}}=0.508$ \\
\hline $\mathrm{R}^{2}$ & & 0.66 & $\operatorname{Sargan}^{\mathrm{b}}: \chi^{2}$ & & {$[0.000]$} \\
\hline
\end{tabular}

Sample: 232 JP firms x 9 years

\begin{tabular}{|c|c|c|c|c|c|}
\hline $\ln \mathrm{L}$ & $0.51^{* * *}$ & $(0.026)$ & $\Delta \ln \mathrm{L}$ & $0.44^{* * *}$ & $(0.076)$ \\
\hline $\ln C$ & $0.14 * * *$ & $(0.026)$ & $\Delta \ln C$ & 0.09 & $(0.099)$ \\
\hline $\ln K$ & $0.16^{* * *}$ & $(0.029)$ & $\Delta \ln K$ & 0.21 & $(0.140)$ \\
\hline lnintraS & -0.03 & $(0.038)$ & $\Delta \operatorname{lnintraS}$ & -0.07 & $(0.061)$ \\
\hline \multirow[t]{3}{*}{ lninterS } & $0.57 * * *$ & $(0.109)$ & $\Delta$ lninterS & 0.28 & $(0.207)$ \\
\hline & & & $\mathrm{AR}(1)$ test & $\mathrm{p}=-2.59$ & $\mathrm{p}>\mathrm{z}=0.009$ \\
\hline & & & $\mathrm{AR}(2)$ test & $p=-0.69$ & $\mathrm{p}>\mathrm{z}=0.492$ \\
\hline
\end{tabular}


Sample: 316 EU firms x 9 years

\begin{tabular}{|c|c|c|c|c|c|}
\hline $\ln \mathrm{L}$ & $0.70^{* * *}$ & $(0.021)$ & $\Delta \ln \mathrm{L}$ & $0.63^{* * *}$ & $(0.056)$ \\
\hline $\ln C$ & $0.09 * * *$ & $(0.028)$ & $\Delta \ln C$ & $0.25^{* *}$ & $(0.110)$ \\
\hline $\ln K$ & $0.10^{* * *}$ & $(0.021)$ & $\Delta \ln K$ & -0.08 & $(0.161)$ \\
\hline lnintraS & -0.02 & $(0.046)$ & $\Delta \operatorname{lnintraS}$ & 0.05 & $(0.067)$ \\
\hline \multirow[t]{3}{*}{ lninterS } & 0.16 & $(0.117)$ & $\Delta \operatorname{lninterS}$ & $0.31 *$ & $(0.187)$ \\
\hline & & & $\operatorname{AR}(1)$ test & $p=-5.71$ & $\mathrm{p}>_{\mathrm{z}}=0.000$ \\
\hline & & & $\operatorname{AR}(2)$ test & $\mathrm{p}=-1.25$ & $\mathrm{p}>_{\mathrm{z}}=0.211$ \\
\hline $\mathrm{R}^{2}$ & & 0.61 & Sargan: $\chi^{2}(96)=160.28$ & & {$[0.000]$} \\
\hline
\end{tabular}

3

4

5

6

7

8

9

10

11

12

13

a: heteroskedastic-consistent standard errors, which are clustered around the firm and the year. b: Sargan is the Sargan-test of over identifying restrictions, the p-value is in squared brackets. c: $\operatorname{AR}(1)$ and $\operatorname{AR}(2)$ are tests for first and second order serial correlation. $* * *, * *$, Coefficient significant at the $1 \%, 5 \%, 10 \%$. Country, Sector and Time dummies are included.

Table 6. Augmented Production Function Estimates by Geographical Area (TRADE intensity procedure)

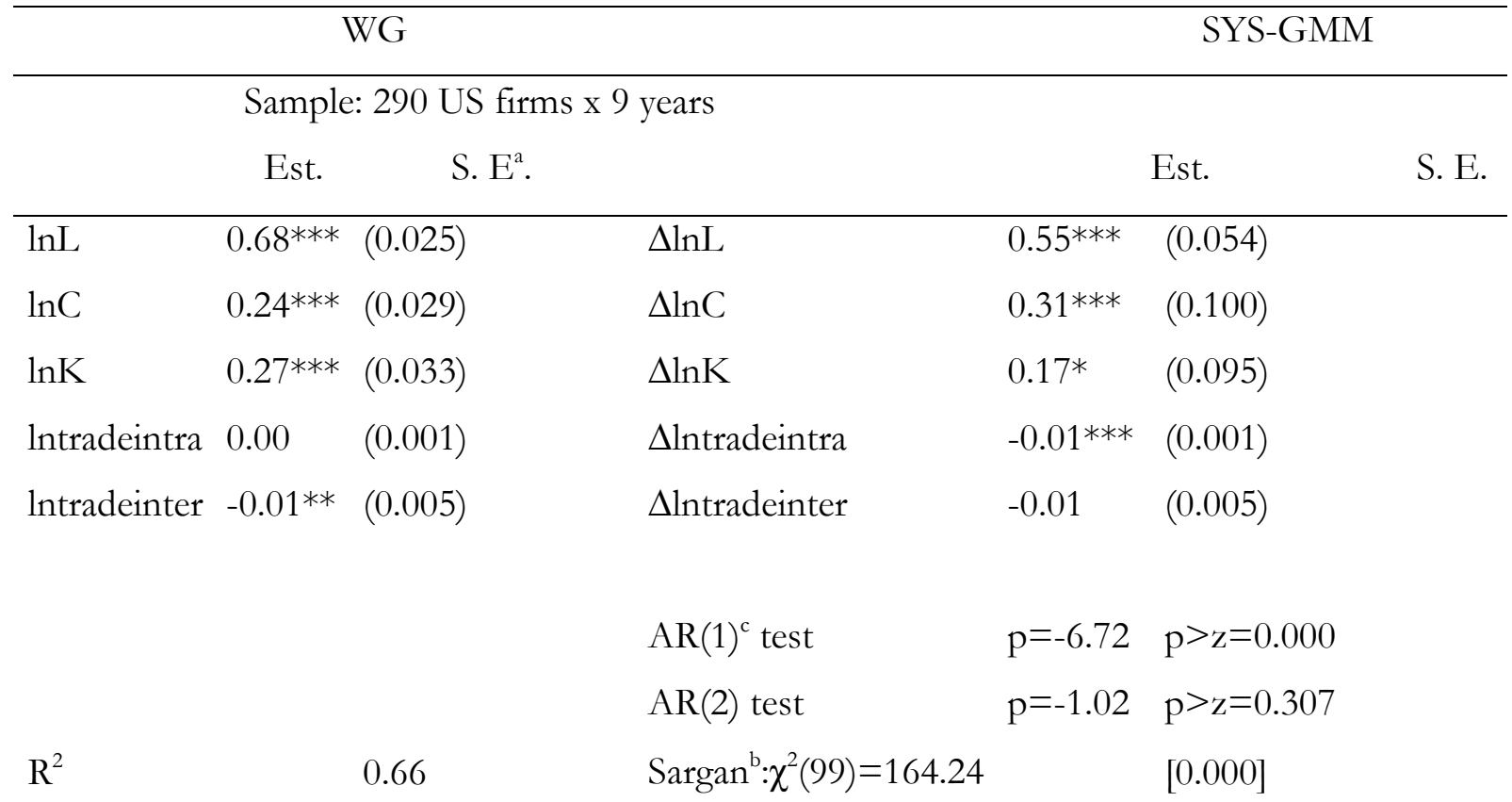

14

15

Sample: 232 JP firms x 9 years

$\ln \mathrm{L} \quad \Delta \ln \mathrm{L}$

$0.40^{* * *}(0.074)$ 


\begin{tabular}{|c|c|c|c|c|c|}
\hline $\ln C$ & $0.17^{* * *}$ & $(0.026)$ & $\Delta \ln C$ & $0.16^{* * *}$ & $(0.062)$ \\
\hline $\ln K$ & $0.13^{* * *}$ & $(0.028)$ & $\Delta \ln \mathrm{K}$ & $0.37 * * *$ & $(0.203)$ \\
\hline \multirow[t]{2}{*}{ lntradeintra } & $0.01 * * *$ & $(0.001)$ & $\Delta \ln$ tradeintra & -0.01 & $(0.001)$ \\
\hline & - & & & & \\
\hline \multirow[t]{3}{*}{ lntradeinter } & $0.04 * * *$ & $(0.008)$ & $\Delta \ln t r a d e i n t e r$ & -0.01 & $(0.026)$ \\
\hline & & & $\mathrm{AR}(1)$ test & $\mathrm{p}=-4.37$ & $\mathrm{p}>\mathrm{z}=0.000$ \\
\hline & & & $\operatorname{AR}(2)$ test & $\mathrm{p}=-1.57$ & $\mathrm{p}>\mathrm{z}=0.117$ \\
\hline $\mathrm{R}^{2}$ & & 0.57 & Sargan: $\chi^{2}(100)=161.71$ & & {$[0.000]$} \\
\hline
\end{tabular}

1

2

\begin{tabular}{|c|c|c|c|c|c|}
\hline $\ln \mathrm{L}$ & $0.69 * * *$ & $(0.021)$ & $\Delta \ln \mathrm{L}$ & $0.61 * * *$ & $(0.059) \quad 3$ \\
\hline $\ln C$ & $0.09 * * *$ & $(0.028)$ & $\Delta \ln C$ & $0.16^{*}$ & $(0.094)$ \\
\hline $\ln K$ & $0.10^{* * *}$ & $(0.020)$ & $\Delta \ln K$ & 0.07 & $(0.064)$ \\
\hline lntradeintra & 0.01 & $(0.001)$ & $\Delta \ln t r a d e i n t r a$ & $-0.01 * * *$ & $(0.001)$ \\
\hline \multirow[t]{3}{*}{ lntradeinter } & $-0.01 *$ & $(0.004)$ & $\Delta \operatorname{lntradeinter}$ & $-0.03^{* * *}$ & $(0.010)$ \\
\hline & & & $\mathrm{AR}(1)$ test & $\mathrm{p}=-5.41$ & $\mathrm{p}>_{\mathrm{z}}=0.000$ \\
\hline & & & $\mathrm{AR}(2)$ test & $p=-1.36$ & $\mathrm{p}>\mathrm{z}=0.173$ \\
\hline $\mathrm{R}^{2}$ & & 0.60 & Sargan: $\chi^{2}(99)=175.84$ & & {$[0.000]$} \\
\hline
\end{tabular}

a: heteroskedastic-consistent standard errors, which are clustered around the firm and the year. b: Sargan is the Sargan-test of over identifying restrictions, the p-value is in squared brackets. c: $\operatorname{AR}(1)$ and $\operatorname{AR}(2)$ are tests for first and second order serial correlation. ${ }^{* *}, * *, *$ Coefficient significant at the 1\%,5\%,10\%. Country, Sector and Time dummies are included.

\subsection{Main Results: The Role of Absorptive Capacity}

In this section, we investigate the role of absorptive capacity and the extent to which it conditions the ability of a firm to benefit from externally produced knowledge. In Tables 7 and 8 , we show the estimates of the production function augmented by our two measures of R\&D spillovers. In both cases, we interact the spillover variables with the firm's existing stock of R\&D. Once we control for the level of absorptive capacity, firms located in the US appear to benefit more from knowledge spillovers from the same industry than from rent spillovers. Vice versa, we 
1 find the opposite result for firms located in Japan that now appear to benefit more from rent

2 spillovers than from knowledge spillovers. These results are in line with our hypotheses and are

3 suggestive of the fact that firms may be specialised in exploiting different types of knowledge

4 from different sources.

5

6 Table 7. Augmented Production Function Estimates by Geographical area - Absorptive Capacity (JAFFE's

7 procedure)

8

9

10

\begin{tabular}{lll}
\hline $\ln \mathrm{L}$ & $0.68^{* * *}$ & $(0.025)$ \\
$\ln \mathrm{C}$ & $0.25^{* * *}$ & $(0.029)$ \\
$\operatorname{lnKintraS}$ & $0.28^{* * *}$ & $(0.050)$ \\
$\operatorname{lnKinterS}$ & -0.07 & $(0.066)$
\end{tabular}

$\mathrm{R}^{2} \quad 0.66$
WG SYS-GMM

Sample: 290 US firms $x 9$ years

Est.

S. E.
11

12

\begin{tabular}{|c|c|c|c|c|c|}
\hline \multicolumn{6}{|c|}{ Sample: 232 JP firms x 9 years } \\
\hline $\ln \mathrm{L}$ & $0.50^{* * *}$ & $(0.026)$ & $\Delta \operatorname{lnL}$ & $0.45^{* * *}$ & $(0.077)$ \\
\hline \multirow[t]{2}{*}{$\ln C$} & $0.14^{* * *}$ & $(0.026)$ & $\Delta \ln C$ & 0.12 & $(0.094)$ \\
\hline & - & & & & \\
\hline lnKintraS & $0.09 * * *$ & $(0.031)$ & $\Delta \operatorname{lnKintraS}$ & $-0.10^{* *}$ & $(0.050)$ \\
\hline \multirow[t]{3}{*}{$\operatorname{lnKinterS}$} & $0.28^{* * *}$ & $(0.044)$ & $\Delta \operatorname{lnKinterS}$ & 0.08 & $(0.071)$ \\
\hline & & & $\mathrm{AR}(1)$ test & $\mathrm{p}=-2.56$ & $\mathrm{p}>\mathrm{z}=0.010$ \\
\hline & & & $\mathrm{AR}(2)$ test & $\mathrm{p}=-0.67$ & $\mathrm{p}>\mathrm{z}=0.502$ \\
\hline $\mathrm{R}^{2}$ & & 0.57 & Sargan: $\chi^{2}(98$ & & {$[0.036]$} \\
\hline
\end{tabular}

13

14

\begin{tabular}{llllll}
\hline \multicolumn{7}{c}{ Sample: 316 EU firms x 9 years } \\
\hline $\ln \mathrm{L}$ & $0.70^{* * *}$ & $(0.021)$ & $\Delta \ln \mathrm{L}$ & $0.62^{* * *}$ & $(0.057)$ \\
$\ln \mathrm{C}$ & $0.09^{* * *}$ & $(0.028)$ & $\Delta \ln \mathrm{C}$ & $0.24^{* * *}$ & $(0.092)$ \\
$\ln$ KintraS & -0.02 & $(0.038)$ & $\Delta \ln$ KintraS & -0.03 & $(0.050)$ \\
$\operatorname{lnKinterS}$ & $0.13^{* * *}$ & $(0.045)$ & $\Delta \ln$ KinterS & -0.08 & $(0.063)$
\end{tabular}

$\begin{array}{lll}\Delta \ln \mathrm{L} & 0.57^{* * *} & (0.051) \\ \Delta \operatorname{lnC} & 0.36^{* * *} & (0.091) \\ \Delta \ln \mathrm{Kin} t r a S & 0.13^{* * *} & (0.063) \\ \Delta \ln K i n t e r S & -0.08 & (0.254) \\ \operatorname{AR}(1)^{\mathrm{c}} \text { test } & \mathrm{p}=-6.70 & \mathrm{p}>\mathrm{z}=0.000 \\ \operatorname{AR}(2) \text { test } & \mathrm{p}=-0.68 & \mathrm{p}>\mathrm{z}=0.498 \\ \operatorname{Sargan}^{\mathrm{b}}: \chi^{2}(97)=186.67 & & {[0.000]}\end{array}$

$\Delta \ln \mathrm{L}$ 


$\begin{array}{llll} & \operatorname{AR}(1) \text { test } & \mathrm{p}=-5.68 & \mathrm{p}>\mathrm{z}=0.000 \\ & \operatorname{AR}(2) \text { test } & \mathrm{p}=-1.30 & \mathrm{p}>_{\mathrm{z}}=0.194 \\ \mathrm{R}^{2} \quad \operatorname{Sargan}^{2} \chi^{2}(97)=159.13 & & {[0.000]}\end{array}$

1

2

5

6

8

9

10

11

12

13

\begin{tabular}{lll}
\hline $\ln \mathrm{L}$ & $0.76^{* * *}$ & $(0.023)$ \\
$\ln \mathrm{C}$ & $0.29 * * *$ & $(0.028)$ \\
$\ln K$ tradeintra & $0.02 * * *$ & $(0.004)$ \\
$\ln K$ tradeinter & $0.02 * * *$ & $(0.006)$
\end{tabular}

$\mathrm{R}^{2} \quad 0.65$

a: heteroskedastic-consistent standard errors, which are clustered around the firm and the year. b: Sargan is the Sargan-test of over identifying restrictions, the p-value is in squared brackets. c: $\operatorname{AR}(1)$ and $\operatorname{AR}(2)$ are tests for first and second order serial correlation. $* * * * *, *$ Coefficient significant at the $1 \%, 5 \%, 10 \%$. Country, Sector and Time dummies are included.

Table 8. Augmented Production Function Estimates by Geographical area - Absorptive Capacity (TRADE intensity procedure)
SYS-GMM

\begin{tabular}{ll}
\hline WG & SYS-GMM
\end{tabular}

Sample: 290 US firms $\mathrm{x} 9$ years
Est.
S. $E^{a}$.

Est.

S. E.

\begin{tabular}{|c|c|c|c|c|}
\hline & & $\operatorname{AR}(1)^{c}$ test & $\mathrm{p}=-3.99$ & $\mathrm{p}>\mathrm{z}=0.000$ \\
\hline & & $\operatorname{AR}(2)$ test & $p=-0.92$ & $\mathrm{p}>\mathrm{z}=0.358$ \\
\hline $\mathbf{D}^{2}$ & 0.65 & $\operatorname{Sargan}^{\mathrm{b}}: \chi^{2}(39)=52.62$ & & {$[0.034]$} \\
\hline
\end{tabular}

14

15

Sample: 232 JP firms x 9 years

\begin{tabular}{|c|c|c|c|c|c|}
\hline $\ln \mathrm{L}$ & $0.53^{* * *}$ & $(0.025)$ & $\Delta \ln \mathrm{L}$ & $0.44 * * *$ & $(0.075)$ \\
\hline $\ln C$ & $0.19 * * *$ & $(0.026)$ & $\Delta \ln C$ & $0.19 * * *$ & $(0.063)$ \\
\hline \multirow[t]{2}{*}{$\operatorname{lnK}$ tradeintra } & $0.01 * *$ & $(0.002)$ & $\Delta \operatorname{lnK}$ tradeintra & $0.02 *$ & $(0.015)$ \\
\hline & - & & & & \\
\hline \multirow[t]{3}{*}{$\operatorname{lnK}$ tradeinter } & $0.02 * * *$ & $(0.009)$ & $\Delta \operatorname{lnK}$ tradeinter & -0.05 & $(0.103)$ \\
\hline & & & $\mathrm{AR}(1)$ test & $p=-4.60$ & $\mathrm{p}>_{\mathrm{z}}=0.000$ \\
\hline & & & $\operatorname{AR}(2)$ test & $\mathrm{p}=-1.56$ & $\mathrm{p}>_{\mathrm{z}}=0.118$ \\
\hline $\mathrm{R}^{2}$ & & 0.58 & Sargan: $\chi^{2}(40)=63.47$ & & {$[0.011]$} \\
\hline
\end{tabular}




\begin{tabular}{|c|c|c|c|c|c|}
\hline $\ln \mathrm{L}$ & $0.72^{* * *}$ & $(0.020)$ & $\Delta \ln \mathrm{L}$ & $0.61 * * *$ & $(0.066)$ \\
\hline $\ln C$ & $0.12^{* * *}$ & $(0.027)$ & $\Delta \ln C$ & $0.22^{* *}$ & $(0.094)$ \\
\hline lnKtradeintra & 0.01 & $(0.002)$ & $\Delta \operatorname{lnK}$ tradeintra & -0.02 & $(0.025)$ \\
\hline \multirow[t]{3}{*}{$\operatorname{lnK}$ tradeinter } & -0.01 & $(0.004)$ & $\Delta \operatorname{lnK}$ tradeinter & -0.05 & $(0.052)$ \\
\hline & & & $\mathrm{AR}(1)$ test & $\mathrm{p}=-4.91$ & $\mathrm{p}>\mathrm{z}=0.000$ \\
\hline & & & $\operatorname{AR}(2)$ test & $\mathrm{p}=-1.15$ & $\mathrm{p}>\mathrm{z}=0.249$ \\
\hline $\mathrm{R}^{2}$ & & 0.60 & Sargan: $\chi^{2}(39)=77.97$ & & {$[0.000]$} \\
\hline
\end{tabular}

1

5

6

7

8

9

10

11

12

13

14

a: heteroskedastic-consistent standard errors, which are clustered around the firm and the year. b: Sargan is the Sargan-test of over identifying restrictions, the p-value is in squared brackets. c: $\operatorname{AR}(1)$ and $\operatorname{AR}(2)$ are tests for first and second order serial correlation. $* * *, * *$, Coefficient significant at the $1 \%, 5 \%, 10 \%$. Country, Sector and Time dummies are included.

As a robustness test, we use our second measure of absorptive capacity based on self-citations.

The results are shown in Table 9 and they show that in the case of Japanese sample, the coefficient associated to the new interaction term is still negative suggesting that even firms that are effective in exploiting their internal knowledge to produce a patentable innovation, they may still not be able to benefit from knowledge spillovers. The analysis per se does not provide an explanation of why this is the case but still it is suggestive of the fact that the capability of producing a patentable innovation may not a sufficient condition for firms to be able to benefit from knowledge spillovers. The results are unchanged in the case of the US-based firms implying that for this group knowledge spillovers still matter.

Table 9. Augmented Production Function Estimates by Geographical area - Absorptive Capacity (JAFFE's procedure)

\section{SYS-GMM}

Sample: 290 US firms x 9 years
Est.
S. $E^{a}$.

$\begin{array}{lll}\Delta \ln \mathrm{L} & 0.54^{* * *} & (0.062) \\ \Delta \ln \mathrm{C} & 0.42^{* * *} & (0.112) \\ \Delta \ln \text { Self*intraS } & 0.14 & (0.087) \\ \Delta \ln \mathrm{n} \text { elf*interS } & -0.36 & (0.317) \\ & & \\ \operatorname{AR}(1)^{\mathrm{c}} \text { test } & \mathrm{p}=-5.09 & \mathrm{p}>\mathrm{z}=0.000 \\ \operatorname{AR}(2) \text { test } & \mathrm{p}=-0.65 & \mathrm{p}>\mathrm{z}=0.516\end{array}$




$\begin{array}{rrr}\Delta \ln \mathrm{L} & 0.55^{* * *} & (0.088) \\ \Delta \ln \mathrm{C} & 0.12 & (0.110)\end{array}$

$\Delta \operatorname{lnSelf} *_{\text {intraS }}$

$\Delta \operatorname{lnSelf} *_{\text {interS }}$

$\begin{array}{lll}\operatorname{AR}(1)^{c} \text { test } & \mathrm{p}=-2.32 & \mathrm{p}>\mathrm{z}=0.020 \\ \operatorname{AR}(2) \text { test } & \mathrm{p}=-0.68 & \mathrm{p}>\mathrm{z}=0.498\end{array}$

$\operatorname{Sargan}^{b}: \chi^{2}(116)=171.76$
$-0.13 \quad(0.084)$

$$
-0.10 \quad(0.339)
$$

[0.001]
3

4

5
$\Delta \ln$ Self*intraS
0.00
(0.099)

$\Delta \operatorname{lnSelf} *_{\text {interS }}$

0.22

(0.374)

$\begin{array}{lll}\operatorname{AR}(1)^{c} \text { test } & \mathrm{p}=-4.30 & \mathrm{p}>\mathrm{z}=0.000 \\ \operatorname{AR}(2) \text { test } & \mathrm{p}=-2.54 & \mathrm{p}>\mathrm{z}=0.011\end{array}$

$\operatorname{Sargan}^{\mathrm{b}}: \chi^{2}(115)=139.00$

[0.063]

6

a: heteroskedastic-consistent standard errors, which are clustered around the firm and the year. b: Sargan is the Sargan-test of over identifying restrictions, the p-value is in squared brackets. c: $A R(1)$ and $\operatorname{AR}(2)$ are tests for first and second order serial correlation. $* * * * *, *$ Coefficient significant at the 1\%,5\%,10\%. Country, Sector and Time dummies are included. 


\section{Conclusions}

4

5 Over the last thirty years, the literature on absorptive capacity has been rather active in trying to identify the internal drivers of absorptive capacity as well as to map its contribution to firm-level performance. Vice versa, very little attention has been paid to how the nature of knowledge being absorbed influences absorptive capacity and how it mediates the relationship between firm-level performance and external knowledge. This paper has tried to fill this gap in the literature by suggesting that firms tend to fine tune their absorptive capacity to the characteristics of the external knowledge they are more likely to get exposure to with the result that firms tend to specialise in acquiring and exploiting specific types of knowledge. We also suggest that the learning strategies (underpinning the absorptive capacity) are conditioned by the external environment as firms that operate in complex innovation ecosystems develop learning strategies that allow to exploit the type of technological knowledge these ecosystems are more likely to produce. As a result, for similar levels of observed absorptive capacity, firms are more likely to benefit from advanced technological knowledge if they operate in an environment where this type of knowledge is more likely to spill over to other firms. To test empirically this hypothesis, we have tested how firm-level absorptive capacity mediates the relationship between rent and pure R\&D spillovers on the one hand and firm-level performance on the other in Europe, Japan and US. The empirical analysis has used a dataset (sourced from the EU R\&D investment scoreboards) made of $879 \mathrm{R} \& \mathrm{D}$-intensive firms. The empirical results suggest for the same level of absorptive capacity, firms in economic areas that are closer to the world technology frontier tend to benefit more from pure (knowledge) spillovers than from rent spillovers. Vice versa, firms located in areas that are not on the technology frontier appear to benefit mostly from rent spillovers that travel along the supply chain. These results suggest that firms tend to update and adapt their learning strategies so to better take advantage of the type of knowledge the firms may get exposed to.

The implications of the paper are quite interesting. First, it confirms the hypothesis that absorptive capacity responds to the external environment and to the characteristics of the external knowledge firms have access to. This is in line with findings from Bosch et al. (1999) and from Makinen and Vilkko (2014) and supports the notion that adaptive capacity can be pathdependent (Vasuveda and Anand, 2011) with the result that firms can be potentially locked in a 
1 particular strategy that may make the firm uncapable of coping with external shocks. Second, it 2 provides some evidence on how absorptive capacity is influenced by the distance of the country 3 from the world technology frontier. In recent years the concept of distance from the frontier has 4 been very useful for studying firms' innovation strategies (Griffith et al., 2004). Research has 5 shown that a firm's position in relation to the technological frontier is an important factor when determining the intensity and nature of innovation in manufacturing. This is one of the few papers showing how the distance from the frontier may influence a firm's internal strategies.

Our empirical analysis can be easily extended in several directions. First, our results cannot be generalised to small and medium enterprises (SMEs) or to temporary R\&D performers. Therefore it would be worth testing our hypotheses to these two sub-sets of firms which may have a narrow, internal knowledge base and not enough resources to adapt their learning strategies to changes in the environment. Second, the analysis can be easily extended to multinationals and it is possible to exploit the distribution of patents' inventors (rather than patents' application) to analyse how multinational firms adapt their local learning strategies to the characteristics of the host country business environment and knowledge base (as in Aldieri and Vinci, 2016b; Aldieri, 2015; Aldieri, 2013).

\section{Acknowledgments}

We would like to thank two anonymous referees and the handling editors for their relevant advice in revising this paper. Any mistake remains our own responsibility.

\section{References}

Aldieri L. (2015). Overlap Citation Proximity within the Triad: Evidence from US and European Patent Citations. Rivista di Politica Economica, April/June, 157-169.

Aldieri L. (2013). Knowledge technological proximity: evidence from US and European patents. Economics of Innovation and New Technology, 22 (8), 807-819.

Aldieri L. and Cincera M. (2009). Geographic and Technological R\&D Spillover within the Triad: micro evidence from US patents. Journal of Technology Transfer, 34, 196-211. 
1 Aldieri L. and Vinci C. P. (2016a). Knowledge Spillover Effects: A Patent Inventor Approach. 2 Comparative Economic Studies, 58(1), 1-16.

3

4 Aldieri L. and Vinci C. P. (2016b). R\&D spillovers and productivity in Italian manufacturing firms. International Journal of Innovation Management, forthcoming.

6

7 Arellano M. and Bond S. (1991). Some tests of Specification for Panel Data: Monte Carlo 8 Evidence and an Application to Employment Equations. The Review of Economic Studies, 58(2), $277-$ 9 297.

10

Arellano M. and Bover. O. (1995). Another look at the instrumental-variable estimation of errorcomponents models. Journal of Econometrics, 68, 29-52.

Arrow K. J. (1962). The economic implications of learning by doing. Review of Economic Studies, 29, 155-172.

Audretsch D. B. and Feldman M. (1996). R\&D Spillovers and the Geography of Innovation and Production. American Economic Review, 86, 630-640.

Arbussa, A. and Coenders, G. (2007). Innovation activities, use of appropriation instruments, and absorptive capacity: evidence from Spanish firms. Research Policy, 36, pp. 1545-1558.

Arora, A., Fosfuri, A. and Gambardella, A. (2001) Markets for Technology and Their Implications for Corporate Strategy. Industrial and Corporate Change, Oxford University Press, vol. 10(2), pages 419-51, June.

Autant-Bernard C., Guironnet J. P. and Massard N. (2011). Agglomeration and social return to R\&D: Evidence from French plant productivity changes. International Journal of Production Economics, 132, 34-42.

Bernard A. B. and Jensen J. B. (2004). Exporting and Productivity in the USA. Oxford Review of Economic Policy, 20, 343-357.

Bloom N., Schankerman M. and Van Reenen J. (2013). Identifying Technology Spillovers and Product Market Rivalry. Econometrica, 81(4), 1347-1393. 
2 Blundell R. W. and Bond S. R. (1998). Initial conditions and moment restrictions in dynamic 3 panel data models. Journal of Econometrics, 87, 115-143.

4

5 Capron H. and Cincera M. (1998). Exploring the spillover impact on productivity of world-wide manufacturing firms. Annales d'Economie et de Statistique, 49/50, 565-587.

7

Carboni O. (2013). Investment in Information and Communication Technologies (ICT): The 9

Role of Geographic distance and Industry Proximity. The Review of Regional Studies, 43(2, 3), 191 212.

Cassiman, B. and Veugelers, R. (2006) In search of complementarity in innovation strategy: internal R\&D and external knowledge acquistion. Management Science, 52, 68-82.

Cincera M. (1998). Economic and technological performances of international firms. PhD thesis, Université Libre de Bruxelles.

Cincera M. and Van Pottelsberghe de la Potterie B. (2001). International R\&D Spillovers: A survey. Cabiers Economiques de Bruxelles, 169, 3-32.

Coe D. T. and Helpman E. (1995). International R\&D Spillovers. European Economic Review, 39(5), 859-887.

Cohen W. M. and Levinthal D. A. (1989). Innovation and learning: the two faces of R\&D, The Economic Journal, 99 (3), 569-596.

Crespi G., Giuri P., Mariani M., Brusoni S., Francoz D., Gambardella A., Garcia-Fontes W., Geuna A., Gonzales R., Harhoff D., Hoisl K., Le Bas C., Luzzi A., Magazzini L., Nesta L., Nomaler O., Palomeras N., Patel P., Romanelli M. and Verspagen B. (2007). Inventors and invention processes in Europe: Results from the PatVal-EU survey. Research Policy, 36(8), 1107 1127.

D’Souza D. E. and Kulkarni S. S. (2015). A framework and model for absorptive capacity in a dynamic multi-firm environment. International Journal of Production Economics, 167, 50-62. 
1 Dimelis S. and Louri H. (2002). Foreign ownership and production efficiency: a quantile regression analysis. Oxford Economic Papers, 54, 449-469.

Driffield N. (2001). The Impact on Domestic Productivity of Inward Investment into the UK. Manchester School, 69, 103-119.

Dyer, J.H. and Singh, H. (1998). The relational view: coop- erative strategy and sources of interorganizational com- petitive advantage. Academy of Management Review, 23, pp. 660-679.

Dussauge P., Garrette B. and Mitchell W. (2000). Learning from competing partners: outcomes and durations of scale and link alliances in Europe, North-America and Asia. Strategic Management Journal, 21(2), 99-126.

European Commission (2011) "The 2011 EU Industrial R\&D Investment Scoreboard" JRCScientific and Technical Research series. http://iri.jrc.ec.europa.eu/scoreboard.html.

Fernandes C. I. and Ferreira J. J. M. (2013). Knowledge spillovers: cooperation between universities and KIBS. R\&DD Management, 43(5), 461-472.

Fosfuri A. and Tribò J.A. (2008) Exploring the antecedents of potential absorptive capacity and its impact on innovation performance. Omega: The International Journal of Management science, 36, 173-187.

Giovannetti E. and Piga C. A. (2017). The contrasting effects of active and passive cooperation on innovation and productivity: Evidence from British Local innovation networks. International Journal of Production Economics, 187, 102-112.

Globerman S. (1975). Technological diffusion in the Canadian tool and the industry. Review of Economics and Statistics, 57, 428-444.

Goto A. and Suzuki K. (1989). R\&D Capital, Rate of Return on R\&D Investment and Spillover of R\&D in Japanese Manufacturing Industries. The Review of Economics and Statistics, 71(4), 555-564.

Grandstrand O., Bohlin E., Oskarsson C. and Sjoberg N. (1992). External technology acquisition in large multi-technology corporations. R\&D Management, 22(2), 111-134. 
1 Grant R. (1996). Toward a knowledge-based theory of the firm. Strategic Management Journal, 2 17(S2), 109-122.

3

4 Griffith R., Harrison R. and Van Reenen J. (2006). How Special is the Special Relationship?

5 Using the impact of US R\&D Spillovers on UK firms as a Test of Technology sourcing. American 6 Economic Review, 96, 1859-1875.

7

8 Griffith R., Redding S. and Van Reenen J. (2004). Mapping the two faces of R\&D: Productivity 9 Growth in a Panel of OECD industries. The Review of Economics and Statistics, 86(4), 883-895. 10

Griffith R., Redding S. and Van Reenen J. (2003). R\&D and Absorptive Capacity: Theory and Empirical Evidence. Scandinavian Journal of Economics, 105(1), 99-118.

Griliches Z. (1979). Issues in assessing the contribution of R\&D to productivity growth. Bell Journal of Economics, 10, 92-116.

Griliches Z. (1992). The search for R\&D Spillovers. Scandinavian Journal of Economics, 94, 29-48.

Grunfeld L. A. (2004). The Multiple Faces of R\&D: Absorptive capacity effects and different sources of spillovers. Norwegian Institute of International Affairs.

Hall B., Lotti F. and Mairesse J. (2009). Innovation and productivity in SMEs: empirical evidence for Italy. Small Business Economics, 33(1), 13-33.

Hansen, M.T. (1999) The search-transfer problem: the role of weak ties in sharing knowledge across organizational subunits. Administrative Science Quarterly, 44, 82-111.

Hoetker G. and Agarwal R. (2007). A faustian bargain? The growth of management and its relationship with related disciplines. Academy of Management Journal, 50(6), 1304-1322.

Ikeuchi K., YoungGak Kim, Hyeog Ug Kwon, and Kyoji Fukao (2013), Productivity Dynamics and R\&D Spillovers in the Japanese Manufacturing Industry: An Empirical Analysis Based on Micro-level Data, Keizai Kenkyu, 64(3): 269-285.

Iršová Z. and Havránek T. (2013). Determinants of Horizontal Spillovers from FDI: Evidence 
Jaffe A. B. (1986). Technological opportunity and spillovers of R\&D: Evidence from firms'

6 Jaffe A. B. (1988). R\&D intensity and productivity growth. Review of Economics and Statistics, 70, $7 \quad 431-437$.

8

\section{9} 10 11

Jaffe A. B., Trajtenberg M. and Henderson R. (1993). Geographic localization of knowledge spillovers as evidenced by patent citations. The Quarterly Journal of Economics, 108, 577-598.

Jansen, J.J., Van den Bosch, F.A.J. and Volberda, H.W. (2005) Managing potential and realized absorptive capacity: how do organizational antecedents matter? Academy of Management Journal, 48, 6, 999-1015.

Jones C. I. (2002). Sources of U.S. Economic Growth in a World of Ideas, American Economic Review”, 92, 220-239.

Kafouros M. I. and Buckley P. J. (2008). Under what conditions do firms benefit from the research efforts of other organizations? Research Policy, 37, 225-239.

Kancs D. and Siliverstovs B. (2016). R\&D and non-linear productivity growth. Research Policy, 35, 634-646.

Keller W. (2002). Geographic Localization of International Technology Diffusion. American Economic Review, 92(1), 120-142.

Kinoshita Y. (2000). R\&D and technology spillovers via FDI: Innovation and absorptive capacity. The William Davidson Institute at the University of Michigan Business School. Working Paper N. 349.

Laursen K. and Salter A. (2006). My precious - The role of Appropriability Strategies in Shaping Innovative Performance. Working Paper 05-02. Danish Research Unit for Industrial Dynamics. 
1 Link A. N., Herzfeld H. R. and Vonortas N. S. (2006). Intellectual property protection 2 mechanism in research partnerships. Research Policy, 35(6), 825-838.

3

4 Lychagin S., Pinkse J., Slade M. E. and Van Reenen J. (2010). Spillovers in Space: Does 5 Geography Matter? NBER Working Paper 16188.

6

7 Makinen, s.J. and Vilkko M.K. (2014), Product Portfolio Decision-Making and Absorptive 8 Capacity: a Simulation Study. Journal of Engineering and Technology Management, 32, 60-75.

9

Mancusi M. L. (2008). International spillovers and absorptive capacity: A cross-country crosssector analysis based on patents and citations. Journal of International Economics, 76 (2), 155-165.

Mangematin, V. and Nesta, L. (1999) What kind of knowledge can a firm absorb? International Journal of Technology Management, 18, 149-172.

Maraut, S., H. Dernis, C. Webb, V. Spiezia, and D. Guellec. 2008. "The OECD REGPAT Database: A Presentation.” STI Working Paper 2008/2, OECD, Paris.

Marshall A. (1890). Principles of Economics. London, UK.

Maurseth P. B. and Verspagen B. (2002). Knowledge spillovers in Europe: A patent citations Analysis. Scandinavian Journal of Economics, 104(4), 531-545.

Mohnen P. (1996). R\&D externalities and productivity growth. STI Review, 18, 39-66.

Muûls M. and Pisu M. (2007). Imports and Exports at the Level of the Firm: Evidence from Belgium. Research series 200705-03. National Bank of Belgium.

Nooteboom, B., Van Haverbeke, W., Duysters, G., Gilsing, V., \& van den Oord, A. (2007). Optimal cognitive distance and absorptive capacity. Research Policy, 36, 1016-1034.

O’Mahony M. and Vecchi M. (2009). R\&D, Knowledge spillovers and company productivity performance. Research Policy, 38, 35-44.

OECD, REGPAT database (accessed January 1, 2012).ftp:/ /prese:Patents@ftp.oecd.org/ 
REGPAT_201301/.

Orlando M. (2004). Measuring Spillovers from Industrial R\&D: On the Importance of Geographic and Technological Proximity, The Rand Journal of Economics, 35(4), 777-786.

Peri G. (2005). Determinants of Knowledge Flows and their Effect on Innovation. Review of Economics and Statistics, 87, 308-322.

Piga C. and Poyago-Theotoky J. (2005). Endogenous R\&D Spillovers and locational choice. Regional Science and Urban Economics, 35(2), 127-139.

Romer P. M. (1986). Increasing returns and long-run growth, Journal of Political Economy, 94, $1002-$ 1037.

Sena V. (2004). Total factor productivity and spillover hypothesis: some new evidence. International Journal of Production Economics, 92-1, 31-42.

Sena V. and Higon D. A. (2014). Productivity, R\&D Spillovers and Educational Attainment, Oxford Bulletin of Economic and Statistics, 76, 1, 1-23.

Siegel D. (2004). Technological change and the Environment: Arnulf Grubler, Nebojsa Nakicenovic, William D. Nordhaus (Eds.), Resources for the Future Press, Washington, DC, 2002, 450 pp., ISBN 1891853-46-5. Structural Change and Economic Dynamics, 15(2), 235-238.

Szulanski, G. (1996). Exploring internal stickiness: impedi- ments to the transfer of best practice within the firm. Strategic Management Journal, 17, pp. 27-43.

Teece D. (1992). Competition, Cooperation and Innovation: Organizational arrangements for regimes of rapid technological progress. Journal of Economic Behavior \& Organization, 18(1), 1-25.

Terleckyj N. E. (1974). Effects of R\&D on the Productivity Growth of Industries: An Exploratory Study, National Planning Association, Washington, DC.

Todorova, G. and Durisin, B. (2007). Absorptive capacity: valuing a reconceptualization. Academy of Management Review, 32, pp. 774-786.

Van den Bosch, F.A.J., Volberda, H.W. and de Boer, M. (1999) Co-evolution of firm absorptive 
1 capacity and knowledge environment: organizational forms and combinative capabilities.

2 Organization Science, 10, 551-568.

3 Van der Panne G. (2004). Agglomeration externalities: Marshall versus Jacob. Journal of 4 Evolutionary Economics, 14, 593-604.

5 Verspagen B. (1997). Measuring Intersectoral Technology Spillovers: Estimates from the 6 European and US Patent Office Databases. Economic Systems Research, 9(1), 47-65.

7

8 Von Hippel E. (1988). The Sources of Innovation. Oxford University Press: Oxford. 9

10 Wolff E. N. and Nadiri I. (1993). Spillover effects, linkage structure, and research and 11 development. Structural Change and Economic Dynamics, 4(2), 315-331.

12

13 Zahra S. A. and George G. (2002). Absorptive Capacity: A Review, A Reconceptualization, and 14 Extension. The Academy of Management Review, 27(2), 185-203.

15

16

17

18

19

20 